\title{
Rekonstruksi Pengaturan Hukum Transaksi Elektronik Di Indonesia
}

\author{
Ahmad Rodli \\ Magister Hukum Fakultas Hukum Universitas Islam Indonesia Yogyakarta Indonesia \\ Jln. Cik Di Tiro No. 1 Yogyakarta Indonesia \\ rodli.luck@gmail.com
}

\begin{abstract}
The development of electronic transaction activities in Indonesia brings its own homework for the legal regime which as it turns out, to this day there are still many problems in the legal regulation of electronic transactions. Departing from this issue, the writer formulates these problems: first, what is the problem with the regulation of electronic transaction law in Indonesia today? Second, what is the urgency of reconstructing the legal regulation of electronic transactions in Indonesia? Third, how should the reconstruction of the legal regulation of electronic transactions in Indonesia be? This is normative juridical research by using conceptual approach and statutory approaches. The results conclude as follows: first, the legal regulation of electronic transactions in Indonesia has several problems, namely (i) it takes a long time to draft the laws and regulations under it, (ii) partial arrangements at different times, (iii) vague legal politics (iv) issues of effectiveness, and (v) issues of harmonization with other laws and regulations; second, the urgency of the legal regulation of electronic transactions is (i) due to the need for legal certainty and legal interests that guarantee the implementation of electronic transactions. (ii) a law is needed that is able to reach future developments and changes, and (iii) because the existing regulations are not yet effective to meet the needs of legal settlements in the field of electronic transactions; third, the reconstruction can be carried out using two methods, namely (i) by making a special law on electronic transactions that are separate from information technology in general and provisions for prohibited acts (cybercrime), and (ii) by using omnibus law legal model of electronic transaction law.
\end{abstract}

Key Words: Electronic transaction; legal arrangement; reconstruction

\begin{abstract}
Abstrak
Perkembangan aktifitas transaksi elektronik di Indonesia membawa pekerjaan rumah tersendiri bagi dunia hukum yang ternyata sampai hari ini masih banyak memiliki problematika dalam pengaturan hukum transaksi elektronik. Berangkat pada isu tersebut penulis merumuskan masalah: pertama, bagaimanakah problematika pengaturan hukum transaksi elektronik di Indonesia saat ini? Kedua, apakah urgensi rekonstruksi pengaturan hukum transaksi elektronik di Indonesia? Ketiga, bagaimanakah rekonstruksi pengaturan hukum transaksi elektronik di Indonesia seharusnya? Jenis penelitian ini yuridis normative, dengan menggunakan pendekatan konseptual dan pendekatan yuridis. Hasil menyimpulkan sebagai berikut. Pertama, pengaturan hukum transaksi elektronik di Indonesia memiliki beberapa problematika, yaitu (i) membutuhkan waktu yang lama untuk menyusun peraturan perundang-undangan di bawahnya. (ii) pengaturan secara parsial dalam waktu yang berbeda. (iii) politik hukum yang kabur (tidak jelas). (iv) persoalan efektifitas, dan (v) persoalan harmonisasi dengan peraturan perundang-undangan yang lain. Kedua, urgensi pengaturan hukum transaksi elektronik adalah (i) dikarenakan perlunya kepastian hukum dan kepentingan hukum yang menjamin penyelenggaraan transaksi elektronik. (ii) diperlukan hukum yang mampu menjangkau perkembangan dan perubahan di masa depan, dan (iii) dikarenakan regulasi yang ada belum efektif untuk memenuhi kebutuhan penyelesaian hukum di bidang transaksi elektronik. Ketiga, rekonstruksi tersebut dapat dilakukan dengan menggunakan dua metode, yaitu (i) dengan membuat undangundang khusus tentang transaksi elektronik yang terpisah dengan teknologi informasi secara umum dan ketentuan-ketentuan perbuatan-perbuatan yang dilarang (cybercrime), serta (ii) dengan menggunakan model hukum omnibus law hukum transaksi elektronik.
\end{abstract}

Kata-kata Kunci: Transaksi elektronik; rekonstruksi; pengaturan hukum 


\section{Pendahuluan}

Teknologi telah memberikan banyak kemudahan bagi manusia sehingga perkembangannya pun terjadi dengan pesat. Dalam hal transaksi pembayaran, telah terjadi pergeseran pola transaksi dari metode konvensional yaitu dengan sistem pembayaran manual menjadi transaksi metode yang lebih canggih, yaitu transaksi elektronik. ${ }^{1}$ Karena kemudahan dan efisiensi waktu yang ditawarkan, metode transaksi inipun dapat dengan cepat berkembang di masyarakat sehingga memunculkan pola baru dalam sistem transaksi pembayaran.

Dari awal kemunculan teknologi tersebut di Indonesia hingga kini telah terjadi peningkatan yang signifikan baik dalam hal jumlah pengguna, volume transaksi, maupun nilai uang yang ditransaksikan menggunakan transaksi elektronik tersebut. Berdasarkan data Bank Indonesia 2019, peningkatan tertinggi dalam volume transaksi elektronik atau uang elektronik di masyarakat terjadi pada 2018 dengan lonjakan volume transaksi sebesar 209,8\% yaitu sejumlah 2,9 miliar transaksi uang elektronik dibandingkan dengan tahun sebelumnya yaitu sebesar 943,3 juta transaksi. ${ }^{2}$

Adapun nilai nominal transaksi uang elektronik juga mengalami kenaikan yang signifikan yaitu sebesar 281,39\% yaitu senilai Rp. 47.200.000.000.000,00 dari pada 2017 yaitu sebesar Rp. 12.400.000.000.000,00. Selisih angka sebesar Rp. 34.800.000.000.000,00 tersebut menunjukkan bahwa telah terjadi kenaikan sebesar hampir 3 kali lipat dari nilai transaksi tahun sebelumnya. ${ }^{3}$ Hingga Juli 2019 nilai transaksi uang elektronik sudah melampaui nilai transaksi pada tahun sebelumnya, yaitu mencapai sebesar Rp. 69.000.000.000.000,00. ${ }^{4}$ Besarnya jumlah pengguna internet dan juga media sosial yang aktif berselancar di dunia maya secara bertahap juga telah membuat perubahan tren lifestyle masyarakat dalam beraktifitas, salah satunya dalam berbelanja. Dengan berbagai kemudahan yang diberikan oleh teknologi internet, membuat masyarakat lebih suka berbelanja

${ }^{1}$ Dalam Pasal 1 angka 2 Undang-Undang Nomor 11 Tahun 2008 disebutkan bahwa Transaksi Elektronik adalah perbuatan hukum yang dilakukan dengan menggunakan Komputer, jaringan Komputer, dan/atau media elektronik lainnya. Hal demikian juga disebutkan dalam Peraturan Pemerintah Nomor 82 Tahun 2012 serta perubahannya yaitu Peraturan Pemerintah Nomor 71 Tahun 2019 dengan pengertian yang sama persis. Dalam Black's Law Dictionary, transaksi elektronik yang dalam bahasa Inggris ditulis Electronik Transaction diartikan sebagai sebuah transaksi yang dilaksanakan melalui pesan elektronik dimana salah satu atau kedua belah pihak tidak akan melalui tahap review terlebih dahulu sebagaimana dalam pembentukan kontrak yang lazim terjadi, lebih jelasnya sebagai berikut teks aslinya: "a transaction formed by electronic messages in which the messages of one or both parties will not be reviewed by an individual as an expected step in forming a contract", (Bryan A. Garner (ed.), Black's Law Dictionary, eight edition, (Publisher: Thomson West, 2004), hlm. 1575.

2 Data Bank Indonesia 2019, dikutip dari artikel online Dwi Hadya Jayani, "Transaksi Uang Elektronik Melonjak 209,8\% pada 2018", dalam https://databoks.katadata.co.id/datapublish/2019/09/23/ transaksi-uangelektronik-melonjak-2098-pada-2018\#. Akses 11 Juli 2020.

${ }^{3}$ Ibid.

${ }^{4}$ Ibid. 
secara online di marketplace atau situs e-commerce. Menurut hasil penelitian McKinsey Indonesia 5 , e-commerce di Indonesia diproyeksikan akan dapat mengalami pertumbuan sebesar delapan kali lipat dari 2017 sampai 2022.

Dengan semakin meningkatnya pengguna internet secara signifikan, yang secara bersamaan juga memberikan dampak peningkatan transaksi jual beli melalui media internet, tentu menjadi sebuah pekerjaan rumah tersendiri bagi regulator untuk memikirkan hal-hal yang dapat timbul sebagai akibat dari kemajuan teknologi tersebut sehingga dibutuhkan hukum yang mengaturnya. Di Indonesia sendiri, secara general, payung hukum penyelenggaraan transaksi elektronik tersebut telah diatur dalam Undang-Undang Nomor 11 Tahun 2008 tentang Informasi dan Transaksi Elektronik. Regulasi lebih rinci tentang pelaksanaan transaksi elektronik kemudian diatur dalam PP Nomor 82 Tahun 2012 tentang Penyelenggaraan Sistem dan Transaksi Elektronik. Peraturan ini kemudian pada 2019 diperbaharui dengan PP Nomor 71 Tahun 2019 tentang Penyelenggaraan Sistem dan Transaksi Elektronik karena peraturan pemerintah sebelumnya dianggap tidak lagi sesuai dengan perkembangan kebutuhan hukum masyarakat ${ }^{6}$ sehingga perlu diganti.

Meskipun telah memiliki payung hukum berupa undang-undang, namun regulasi tentang transaksi elektronik dinilai masih belum efektif. Sebagaimana diketahui bahwa tidak sedikit jumlah regulasi yang mengatur penyelenggaraan transaksi elektronik yang masing-masing dikeluarkan oleh lembaga yang berbeda-beda. Peraturan perundang-undangan yang berjumlah banyak dan bersumber dari berbagai lembaga tersebut tentu membuka peluang terjadinya konflik hukum, sehingga perlu dicarikan rumusan yang tepat mengenai model hukum yang sesuai untuk mengatur transaksi elektronik di Indonesia.

\section{Rumusan Masalah}

Pokok masalah penelitian ini dituangkan dalam tiga rumusan masalah berikut, yaitu: pertama, bagaimanakah problematika pengaturan hukum transaksi elektronik di Indonesia saat ini? Kedua, apakah urgensi terhadap perlunya rekonstruksi pengaturan hukum transaksi elektronik di Indonesia? Ketiga, bagaimanakah rekonstruksi pengaturan hukum transaksi elektronik di Indonesia seharusnya?

${ }^{5}$ Kaushik Das, dkk., 'The Digital Archipelago: How Online Commerce is Driving Indonesia's Economic Development", McKinsey \& Company, 2018, hlm. 13. Laporan e-paper diunduh dari http://www.mckinsey.com/featured-insights/asia-pacific/the-digital-archipelago-how-online-commerce-isdriving-Indonesias-economic-development.

6 Lihat konsideran Peraturan Pemerintah Republik Indonesia Nomor 71 Tahun 2019 tentang Penyelenggaraan Sistem dan Transaksi Elektronik. 


\section{Tujuan Penelitian}

Penelitian ini disusun penulis dengan tujuan berikut: pertama, mengidentifikasi problematika pengaturan hukum transaksi elektronik di Indonesia. Kedua, mengkaji urgensi dari rekonstruksi hukum transaksi elektronik di Indonesia. Ketiga, mengusulkan konsep rekonstruksi pengaturan hukum dalam bidang transaksi elektronik di Indonesia yang seharusnya

\section{Metode Penelitian}

Penelitian ini menggunakan jenis penelitian normatif dengan dua pendekatan, yaitu pendekatan konseptual dan pendekatan undang-undangan atau yuridis. Pendekatan konseptual dalam hal ini yaitu pendekatan yang beranjak dari pandangan-pandangan dan doktrin-doktrin yang berkembang di dalam ilmu hukum, khususnya hukum tata negara dan hukum siber (cyber law). Melalui pendekatan konseptual ini penulis merekonstruksi kerangka berpikir tentang hukum peraturan perundang-undangan dalam penyelenggaraan transaksi elektronik di Indonesia. Sedangkan pendekatan kedua, yaitu pendekatan undang-undang atau disebut juga pendekatan yuridis, diperlukan untuk menganalisis peraturan perundang-undangan yang mengatur atau paling tidak bersinggungan dengan transaksi elektronik.

Data penelitian dalam penelitian hukum normatif disebut dengan istilah bahan hukum. Bahan hukum yang digunakan dalam penelitian ini yaitu sebagai berikut:

a. Bahan hukum primer, di antaranya yaitu UU Nomor 11 Tahun 2008 tentang Informasi dan Transaksi Elektronik (UU ITE) beserta perubahannya yaitu UU Nomor 19 Tahun 2016, serta peraturan perundang-undangan lain di bawahnya seperti PP Nomor 82 Tahun 2012, PP Nomor 71 Tahun 2019, dan PP Nomor 80 Tahun 2019.

b. Bahan hukum sekunder, di antaranya naskah ademik, dokumen rapat pembentukan peraturan perundang-undangan, buku-buku, jurnal, artikel, media informasi online, serta dokumen pustaka lainnya yang memiliki kaitan dengan pembahasan penelitian ini.

c. Bahan hukum tersier, yakni bahan hukum yang memberikan petunjuk maupun penjelasan terhadap bahan hukum primer dan sekunder, yaitu kamus dan ensiklopedia.

Teknik pengumpulan data dalam penelitian ini dilakukan melalui studi dokumen atau kepustakaan. Bahan hukum yang diperoleh dalam penelitian ini dikaji sehingga dapat diuraikan dan dihubungkan secara sistematis kemudian dikelompokkan sesuai dengan jenis bahan hukumnya. Pertama, yaitu 
menguraikan bahan hukum primer dengan mengurai peraturan yang ada dalam UU ITE, PP Nomor 82 Tahun 2012, PP Nomor 71 Tahun 2019, dan PP Nomor 80 Tahun 2019. Kedua, dilanjutkan dengan bahan-bahan hukum sekunder seperti buku-buku dan data pustaka lainnya yang secara spesifik mengandung muatan tentang pengaturan transaksi elektronik yang kemudian dielaborasi sesuai dengan kegunaannya sebagai penjelas dari bahan hukum primer. Bahan hukum yang sudah diolah disajikan secara kualitatif, dengan menggunakan uraian deskriptif, yaitu dengan mendeskripsikan data yang diperoleh ke dalam bentuk penjelasan.

\section{Hasil Penelitian dan Pembahasan}

\section{Transaksi Elektronik dan Perundang-undangan}

Istilah transaksi elektronik sendiri merujuk pada beberapa definisi. Hal ini berkaitan dengan singgungan istilah transaksi elektronik dengan istilah electronic commerce (e-commerce), yang menjadikannya dianggap sebagai bagian dari ecommerce, ${ }^{7}$ karena hampir seluruh aktifitas transaksi elektronik muncul dari praktik e-commerce, bahkan berkembang pesatnya transaksi elektronik juga merupakan buah yang lahir dari perkembangan perdagangan secara online. ${ }^{8} \mathrm{Di}$ dalam EFTA (Undang-Undang Transfer Dana Elektronik) Amerika Serikat tahun 1978, dijelaskan bahwa EFT (Elektronic Fund Transfer) merupakan "transfer dana yang dimulai melalui terminal elektronik, telepon, komputer (termasuk perbankan online) atau pita magnetik untuk tujuan memesan, menginstruksikan, atau memberi otorisasi kepada lembaga keuangan untuk mendebit atau mengkredit rekening konsumen, ${ }^{9}$ atau aktifitas transfer uang antar rekening dengan sistem elektronik seperti Automated Teller Machines (ATM) -dalam bahasa Indonesia diterjemahkan menjadi Anjungan Tunai Mandiri- dan pembayaran elektronik atas tagihan yang bukan dilakukan melalui cek atau tunai. ${ }^{10}$ EFT inilah yang dianggap sebagai embrio aktifitas transaksi elektronik di dunia.

Di sisi lain, dalam sebagian penelitian, dijelaskan bahwa embrio transaksi elektronik - atau dalam istilah lain disebut pembayaran online (online payment) -

${ }^{7}$ Enni Soerja Priowirjanto, "Pengaturan Transaksi Elektronik dan Pelaksanaannya di Indonesia Dikaitkan dengan Perlindungan E-Konsumen”, Padjadjaran Jurnal Ilmu Hukum, Volume 1, Nomor 2, Tahun 2014, hlm. 290.

8 Shinta Dewi, Cyberlaw 1 Perlindungan Privasi Atas Informasi Pribadi Dalam E- commerce Menurut Hukum International, Widya Padjajaran, Bandung, 2009, hlm. 54.

${ }^{9}$ The Electronic Fund Transfer Act (EFTA) (15 USC 1693 et seq.) 1978, (Section 205.3. (b)).

10 Glossary of Banking Terms and Phrases, https://www.helpwithmybank.gov/glossary/indexglossary.html, dikases pada 5 Juni 2021. 
mulai muncul pada $1918^{11}$ ketika currency (mata uang) pertama kali dipindahkan ke Amerika Serikat oleh Federal Reserve Bank dengan bantuan teknologi Telegraf. Namun demikian, teknologi tersebut belum banyak digunakan di Amerika Serikat sampai pada saat didirikannya Automated Clearing House (ACH $)^{12}$ pada 1972 yang kemudian menjadikan pembayaran elektronik semakin populer. ${ }^{13}$ Berbagai bentuk praktik transaksi melalui media elektronik tersebut terus mengalami perkembangan seiring berkembangnya e-commerce dan teknologi internet, hingga saat ini dikenal berbagai bentuk transaksi elektronik yang biasa digunakan oleh masyarakat. Meskipun demikian, hingga saat ini definisi tentang transaksi elektronik masih memiliki banyak variasi.

Peraturan perundang-undangan merupakan istilah yang lazim digunakan dalam sistem ketatanegaraan untuk menyebut sebuah sistem maupun produk hukum yang mengatur tentang suatu hal. Secara teoretik, terdapat beberapa pendapat mengenai pengertian perundang-undangan serta hal-hal yang melingkupinya. Penggunaan istilah ilmu pengetahuan perundang-undangan merupakan penyebutan yang digunakan oleh A. Hamid S. Attamimi pada 1975 yang diterjemahkan dari istilah Gesetzgebungswissenschaft, atau kerap juga disebut dengan istilah Wetgevingswetenschap atau Science of Legislation. ${ }^{14}$ Selain A. Hamid S. Attamimi, terdapat pula beberapa tokoh lain di dunia yang memunculkan istilah penyebutan ilmu pengetahuan perundang-undangan. Sebut saja Peter Noll pada 1973 yang menggunakan istilah Gesetzgebungslehre, ada pula Jürgen Rödig pada 1975 yang menggunakan istilah Gesetzgebungslehre, Burkhardt Krems pada 1979 dan Warner Maihofer pada 1981 yang menggunakan istilah Gesetzgebungswissenschaff, S.O. van Poelje pada 1980 menggunakan istilah Wetgevingsleer atau Wetgevingskunde, serta W.G. van der Velden pada tahun 1988 yang menggunakan istilah Wetgevingstheorie. ${ }^{15}$

Soehino, ${ }^{16}$ menyatakan bahwa peraturan Perundang-undangan memiliki dua makna, yaitu pertama, merupakan proses atau tata cara pembentukan peraturan Perundang-undangan negara dari jenis dan tingkat tertinggi yaitu

${ }^{11}$ Burhan Ul Islam Khan, dkk., "A Compendious Study of Online Payment Systems: Past Developments, Present Impact, and Future Considerations”, IJACSA (International Journal of Advanced Computer Science and Applications), Vol. 8, No. 5, 2017, hlm. 258.

12 ACH digunakan di beberapa negara tertentu seperti negara-negara di Amerika, Eropa dan India. Menurut European Central Bank (ECB), ACH merupakan sistem kliring elektronik di mana perintah pembayaran saling dipertukarkan di antara peserta sendiri (terutama melalui media elektronik) dan ditangani oleh pemrosesan data pusat. (Lihat European Central Bank, "Glossary of Terms Related to Payment, Clearing and Settlement Systems”, 2009, hlm. 2).

${ }^{13}$ Burhan UI Islam Khan, Loc. Cit.

${ }^{14}$ Maria Farida Indrati S., Ilmu Perundang-undangan 1 Jenis, Fungsi, dan Materi Muatan, Penerbit PT. Kanisius, Yogyakarta, 2007, hlm. 7.

15 Ibid.

${ }^{16}$ Soehino, Hukum Tata Negara: Teknik Perundang-undangan, Penerbit Liberty, Yogyakarta, 1981, hlm. 1. 
undang-undang sampai yang terendah, yang dihasilkan secara atribusi atau delegasi dari kekuasaan perundang-undangan. Sedangkan makna kedua yaitu merupakan keseluruhan produk peraturan-peraturan perundangan tersebut.

Adapun konsep hirarkis dalam peraturan perundang-undangan berangkat dari teori sistem hukum yang diperkenalkan oleh Hans Kelsen yang menyatakan bahwa sistem hukum merupakan sistem anak tangga dengan kaidah berjenjang. Hubungan antara norma yang mengatur perbuatan norma lain dan norma lain tersebut dapat disebut sebagai hubungan super dan sub-ordinasi dalam konteks spasial. ${ }^{17}$ Sistem norma statik merupakan sistem yang melihat pada isi norma. Menurut sistem norma yang statik, norma umum dapat ditarik menjadi norma yang lebih khusus, atau norma-norma khusus itu dapat ditarik dari suatu norma yang umum. Sedangkan sistem norma yang dinamik adalah sistem norma yang melihat pada berlakunya suatu norma dari cara pembentukannya atau penghapusannya. ${ }^{18}$ Berdasarkan dua klasifikasi norma tersebut, dalam hal ilmu perundang-undangan yang digunakan adalah norma kedua, yaitu norma hukum sebagai suatu norma yang dinamik, yang berarti norma yang diterapkan berdasarkan siapa pembuatnya dan bagaimana penerapannya dikaitkan dengan norma-norma lainnya. ${ }^{19}$

Pada generasi selanjutnya, Stufentheorie Hans Kelsen tersebut dikembangkan lebih lanjut oleh muridnya yaitu Hans Nawiasky dengan melahirkan gagasan theorie von stufenufbau der rechtsordnung. Berdasarkan teori ini, susunan norma hukum peraturan perundang-undangan sebuah negara terdiri dari beberapa tingkatan yaitu sebagai berikut: ${ }^{20}$

a. Staatsfundamentalnorm

b. Staatsgrundgesetz

c. Formell gesetz

d. Verordnung en Autonome Satzung

A Hamid S. Attamimi menjabarkan susunan hirarki di atas dalam disertasinya, dengan penjelasan bahwa yang dimaksud dengan Staatsfundamentalnorm dalam hirarki Hans Nawiasky di atas yaitu norma fundamental sebuah negara yang merupakan dasar bagi pembentukan konstitusi atau Undang-Undang Dasar. Dalam konteks Indonesia, maka Staatsfundamentalnorm tersebut adalah Pancasila (Pembukaan Undang-Undang

17 Jimly Asshiddiqie dan M. Ali Safa'at, Theory Hans KelsenTentang Hukum, Cetakan ke-1, Sekretariat Jendreral \& Kepaniteraan Makamah Konstitusi RI, Jakarta, 2006, hlm. 110.

18 Ibid.

${ }^{19}$ Ibid.

20 Sony Maulana Sikumbang, dkk., Imu Perundangan-undangan, Universitas Terbuka, Jakarta, 2016 hlm. 1.34-1.35. 
Dasar Negara Republik Indonesia Tahun 1945). Staatsgrundgesetz merupakan aturan dasar atau aturan pokok negara, dalam konteks Indonesia, Staatsgrundgesetz Batang Tubuh UUD 1945, Tap MPR, dan Konvensi Ketatanegaraan. Formell gesetz merupakan undang-undang formal sebagaimana undang-undang yang ada di Indonesia. Sedangkan Verordnung en Autonome Satzung merupakan aturan pelaksana atau aturan otonom mulai dari Peraturan Pemerintah hingga Keputusan Bupati atau Walikota. ${ }^{21}$

\section{Rekonstruksi Pengaturan Hukum Transaksi Elektronik}

Pengaturan hukum transaksi elektronik di Indonesia mengacu pada Undang-Undang Nomor 11 Tahun 2008 tentang Informasi dan Transaksi Elektronik. Undang-undang ini memuat beberapa materi kaitannya pengaturan teknologi informasi dan kegiatan traksasi elektronik. Undang-Undang Nomor 11 Tahun 2008 tentang Informasi dan Transaksi Elektronik juga mengatur teknis penyelenggaraan teknologi informasi dan transaksi elektronik. Pengaturan teknis tersebut diamanatkan dengan membentuk pembentukan Peraturan Pemerintah yang mengatur lebih lanjut tentang: Lembaga Sertifikasi Keandalan, Tanda Tangan Elektronik, Penyelenggara Sertifikasi Elektronik, Penyelenggaraan Sistem Elektronik, Penyelenggaraan Transaksi Elektronik, Penyelenggara Agen Elektronik, Pengelolaan Nama Domain, Tata Cara Intersepsi, Peran Pemerintah tentang Pemanfaatan Teknologi Informasi dan Transaksi Elektronik ${ }^{22}$

Meskipun diberi waktu oleh undang-undang untuk menetapkan peraturan turunan tersebut paling lambat 2 tahun setelah diundangkannya Undang-Undang Nomor 11 Tahun 2008 tentang Informasi dan Transaksi Elektronik, namun sampai waktu tersebut habis belum ada Peraturan Pemerintah yang lahir, hingga pada 2012 terbitlah PP Nomor 82 Tahun 2012 tentang Penyelenggaraan Sistem dan Transaksi Elektronik (PP PSTE) yang kemudian dirubah dengan peraturan pemerintah terbaru yaitu PP Nomor 71 Tahun 2019 tentang Penyelenggaraan Sistem dan Transaksi Elektronik.

Selain peraturan tersebut, terdapat juga peraturan perundang-undangan lainnya yang mengatur atau paling tidak bersinggungan dengan kegiatan transaksi elektronik. Peraturan tersebut di antaranya yaitu PP Nomor 80 Tahun 2019 tentang Perdagangan Melalui Sistem Elektronik (PP PMSE), Peraturan Presiden Nomor 74 Tahun 2017 tentang Peta Jalan Sistem Perdagangan Nasional

21 A. Hamid S. Atamimi, "Peranan Keputusan Presiden Republik Indonesia dalam Penyelenggaraan Pemerintahan Negara; Suatu Studi Analisis Mengenai Keputusan Presiden yang Berfungsi Pengaturan dalam Kurun Waktu Pelita I-Pelita IV”, Disertasi Ilmu Hukum Fakultas Pascasarjana Universitas Indonesia, Jakarta, 1990, hlm. 287.

22 Pasal 40 ayat (6) Undang-Undang Nomor 11 Tahun 2008 
Berbasis Elektronik (Road Map e-Commerce), Peraturan Presiden Nomor 95 Tahun 2018 tentang Sistem Pemerintahan Berbasis Elektronik (SPBE), Peraturan Menteri Komunikasi dan Informatika Nomor 36 Tahun 2014 tentang Tata Cara Pendaftaran Penyelenggara Sistem Elektronik, Peraturan Menteri Komunikasi dan Informatika Nomor 11 Tahun 2018 tentang Penyelenggaraan Sertifikasi Elektronik, Peraturan Otoritas Jasa Keuangan Nomor 13 Tahun 2018 tentang Inovasi Jasa Keuangan Digital, Peraturan Otoritas Jasa Keuangan Nomor 77 Tahun 2016 tentang Layanan Pinjam Meminjam Uang Berbasis Teknologi Informasi.

Dari uraian tersebut terlihat bahwa meskipun pengaturan hukum transaksi elektronik menginduk di UU Nomor 11 Tahun 2008 tentang Informasi dan Transaksi Elektronik, namun menghasilkan peraturan turunan dengan berbagai bentuk dan berasal dari beberapa lembaga yang berbeda. Kondisi pengaturan hukum transaksi elektronik yang demikian tidak dapat dipungkiri dapat menyisakan berbagai problematika tersendiri. Berdasarkan kajian penulis terdapat beberapa problematika yang patut menjadi bahasan akibat model hukum seperti itu. Problematika pengaturan hukum transaksi elektronik di Indonesia adalah sebagai berikut:

a. Butuh waktu yang lama untuk menyusun peraturan perundang-undangan UU Nomor 11 Tahun 2008 tentang Transaksi Elektronik mengamanatkan untuk membentuk peraturan turunan berupa peraturan pemerintah yang mengatur tentang Lembaga Sertifikasi Keandalan, Tanda Tangan Elektronik, dan beberapa poin lain paling lambat 2 tahun setelah diundangkannya UU Nomor 11 Tahun 2008. Meskipun sudah ditentukan batasan waktunya, namun realisasi pembentukan peraturan pemerintah tentang poin-poin di atas mundur hingga 2 tahun. Peraturan tersebut baru terrealisasi pada tahun 2012 dengan di tetapkannya PP Nomor 82 Tahun 2012 tentang tentang Penyelenggaraan Sistem dan Transaksi Elektronik (PP PSTE).

Hal ini juga terjadi pada peraturan turunan selanjutnya. PP Nomor 82 Tahun 2012 tentang PSTE menyebutkan bahwa perlunya menetapkan Peraturan Menteri Komunikasi dan Informatika tentang Tata Cara Pendaftaran Penyelenggara Sistem Elektronik. ${ }^{23}$ Setelah membutuhkan waktu selama 2 tahun, Menteri Komunikasi dan Informatika baru menerbitkan peraturan tersebut dengan Peraturan Menteri Komunikasi dan Informatika Nomor 36 Tahun 2014 tentang Tata Cara Pendaftaran Penyelenggara Sistem Elektronik. Hal yang sama juga terlihat pada Pasal 59 ayat (5) dan 62 ayat (4) yang menyebutkan perlunya menetapkan Peraturan Menteri Komunikasi dan

23 Pasal 5 ayat (5) Peraturan Pemerintah Nomor 82 Tahun 2012. 
Informatika tentang Penyelenggaraan Sertifikasi Elektronik. Peraturan tersebut baru terbit setelah membutuhkan waktu selama 6 tahun yaitu pada saat diterbitkannya Peraturan Menteri Komunikasi dan Informatika Nomor 11 Tahun 2018 tentang Penyelenggaraan Sertifikasi Elektronik.

b. Pengaturan secara parsial dalam waktu yang berbeda

Transaksi elektronik lahir salah satunya dilatarbelakangi oleh semakin massifnya fenomena perdagangan elektronik (e-commerce) di Indonesia, sehingga dua hal ini seharusnya menjadi satu paket yang beriringan ketika membicarakan soal regulasi. Namun tidak demikian yang terjadi. Pengaturan hukum yang lebih teknis mengenai e-commerce yaitu mengenai road map muncul pada 2017 melaui Peraturan Presiden Nomor 74 Tahun 2017 tentang Peta Jalan Sistem Perdagangan Nasional Berbasis Elektronik (Road Map e-Commerce).

Peraturan perundang-undangan mengenai e-commerce muncul kembali secara terpisah 2018. Peraturan ini muncul ketika Pemerintah mengeluarkan PP Nomor 80 Tahun 2019 tentang Perdagangan Melalui Sistem Elektronik (PP PMSE). Pengaturan hukum secara parsial dan dalam periode waktu yang berbeda sebagaimana disebutkan di atas tentu sangat mempengaruhi efektifitas hukum transaksi elektronik di Indonesia. Pasalnya, regulasi dengan model seperti itu cukup menyulitkan masyarakat untuk dapat mengetahui pengaturan hukum secara komprehensif.

c. Politik hukum yang kabur

Politik hukum dalam pengaturan hukum transaksi elektronik di Indonesia dapat dibilang masih belum begitu jelas atau kabur. Hal ini terlihat dalam beberapa kasus yang timbul kaitannya dengan peraturan mengenai transaksi elektronik yang memperlihatkan politik hukum yang berbeda atau berubah antara satu peraturan dengan peraturan lainnya. Perbedaan tersebut misalnya terdapat dalam konteks perlindungan keamanan negara yang dapat dilihat dalam PP Nomor 71 Tahun 2019 tentang Penyelenggaraan Sistem dan Transaksi Elektronik. Dalam PP Nomor 71 Tahun 2019 disebutkan terdapat dua opsi terkait penempatan data center penyelenggara sistem elektronik, yaitu bagi penyelenggara sistem elektronik publik wajib menempatkan pusat data atau server beserta pengelolaannya di wilayah Indonesia, ${ }^{24}$ sedangkan bagi penyelenggara sistem elektronik privat diberikan kebebasan untuk dapat menempatkan pusat datanya di wilayah Indonesia ataupun di luar wilayah Indonesia. ${ }^{25}$

Pembolehan penempatan data center di luar wilayah Indonesia menunjukkan bahwa misi perlindungan keamanan negara bukan lagi menjadi hal yang

24 Pasal 20 Peraturan Pemerintah Nomor 71 Tahun 2019.

25 Pasal 21 Peraturan Pemerintah Nomor 71 Tahun 2019. 
penting bagi Indonesia mengingat di era saat ini, data merupakan suatu yang berharga dan memiliki nilai penting 26 bagi keamanan suatu negara. Karena dengan pembolehan penempatan data center tersebut artinya suatu saat dapat mengancam kedaulatan data nasional.

Sebagai penguat, ketentuan ini juga dapat dibandingkan dengan Perpres Nomor 74 Tahun 2017 tentang Peta Jalan Sistem Perdagangan Nasional Berbasis Elektronik (Road Map E-Commerce) pada 2017-2019. Dalam Perpres tersebut disebutkan bahwa peta jalan SPNBE 2017-2019 dilaksanakan dengan prinsip pengutamaan dan perlindungan terhadap kepentingan nasional dan usaha mikro, kecil, dan menengah serta usaha pemula (start-up). ${ }^{27}$ Dari Perpres tersebut dapat diihat bahwa politik hukum mengenai perlindungan terhadap kepentingan nasional menjadi prioritas utama.

d. Persoalan efektifitas

Contoh riil dalam hal ini adalah mengenai penyelesaian sengketa dengan opsi ODR (Online Dispute Resolution). Jika mengacu pada regulasi yang ada, peraturan perundang-undangan di Indonesia telah memberikan alternatif penyelesaian sengketa transaksi elektronik menggunakan metode ini. Hal itu tercantum dalam Undang-Undang Nomor 11 Tahun 2008 tentang Informasi dan Transaksi Elektronik dan juga dalam Peraturan Pemerintah Nomor 80 Tahun 2019 tentang Perdagangan Melalui Sistem Elektronik (PP PMSE). ${ }^{28}$

Hal ini menarik jika dikaji dari aspek efektifitas penerapannya. Penyelesaian melalui ODR hingga kini masih sulit diterapkan di Indonesia dikarenakan support system yang belum memadai. Infrastruktur internet sangat berpegaruh terhadap dapat dilaksanakan atau tidaknya ODR, namun sebagaimana hasil laporan GSMA, fasilitas jaringan internet hingga hari ini belum merata di seluruh wilayah Indonesia. ${ }^{29}$

${ }^{26}$ Mengacu pada pendapat Hammer, data atau dalam bahasa lain disebut informasi memang merupakan komoditi yang penting. Data dapat diduplikasi/dikopi, diciptakan, disalahartikan, didistorsi bahkan dapat dicuri. Menurutnya, data atau informasi merupakan salah satu dari tiga sumber daya dasar (basic resources) di era saat ini selain energi dan potensi material. Lihat Rogers, Communication Technology: The New Media in Society, 1991, terjemah oleh Zulkarnaina Mohd Mess, Teknologi Komunikasi: Media baru Dalam Masyarakat, Dewan Bahasa dan Pustaka, Kuala Lumpur, 1991, hlm. 84.

27 Pasal 3 ayat (4) huruf c Peraturan Presiden Nomor 74 Tahun 2017.

28 Penyelesaian sengketa elektronik melalui ODR dinyatakan secara eksplisit dalam PP PMSE Pasal 72 ayat (2) yang berbunyi: "Penyelesaian sengketa PMSE sebagaimana dimaksud ayat (1) dapat diselenggarakan secara elektronik (online dispute resolution) sesuai dengan ketentuan peraturan perundang-undangan."

29 Berdasarkan laporan GSMA, sebuah asosiasi yang mengkaji tentang pengguna operator seluler di seluruh dunia, Indonesia masih tergolong dalam kategori Transitioners, dengan skor indeks konektivitas di angka 61,4 dari total angka 100. Data 2018 tersebut menunjukkan bahwa Indonesia masih berada di bawah rata-rata indeks negara-negara tetangga seperti Singapura $(86,4)$ yang masuk dalam kategori Leaders, serta Thailand $(67,9)$, Malaysia $(67,1)$, dan Brunei Darussalam $(66,9)$ yang masuk dalam kategori Advanced. Lihat GSMA Association, Connected Society: The State of Mobile Internet Connectivity 2019, hlm. 41. 
e. Persoalan harmonisasi dengan peraturan perundang-undangan yang lain Persoalan lainnnya yang tidak kalah penting yaitu tentang harmonisasi dengan peraturan perundang-undangan yang lain. Tidak dapat dipungkiri bahwa transaksi elektronik telah memberikan efek domino terhadap sektor kehidupan yang lain yang secara otomatis regulasinya juga akan mengantarkan pada singgungan regulasi di bidang lainnya. Hal inilah yang melatarbelakangi peliknya upaya harmonisasi pengaturan hukum transaksi elektronik dengan perundang-undangan lainnya.

Contoh riil dari persoalan ini yaitu dengan lahirnya Undang-Undang Nomor 11 Tahun 2008 telah menimbulkan persoalan harmonisasi dengan peraturan lainnya. Kementrian Komunikasi dan Informatika misalnya, pernah mencatat bahwa terdapat 21 undang-undang yang bisa terkena dampak dari Undang-Undang Nomor 11 Tahun 2008 tersebut. 30 Undang-undang tersebut antara lain seperti UndangUndang Nomor 5 Tahun 1999 tentang Larangan Praktek Monopoli dan Persaingan Usaha Tidak Sehat, Undang-Undang Nomor 19 Tahun 2002 tentang Hak Cipta, dan Undang-Undang 15 Tahun 2001 tentang Merk. ${ }^{31}$

Dari bahasan tersebut dapayt diketahui bahwa terdapat berbagai persoalan yang muncul dari regulasi tersebut, mulai dari pengaturan yang bersifat parsial, terpisah dan muncul pada rentang waktu yang berbeda sehingga tidak cukup efektif dan komprehensif untuk memayungi praktik transaksi elektronik yang begitu kompleks. Karena hal itu, menjadi suatu urgensi tersendiri untuk melakukan rekonstruksi pengaturan hukum transaksi elektronik di Indonesia. Urgensi ini berdasarkan kajian penulis dilatarbelakangi beberapa hal, yaitu sebagai berikut:

a. Kepastian dan Kepentingan Hukum

Kepastian hukum muncul dari landasan pemikiran tentang perlunya normanorma hukum dalam setiap produk hukum yang lahir. Sebagaimana dikatakan Hans Kelsen, bahwa hukum merupakan sebuah sistem norma. Norma adalah pernyataan yang menekankan aspek "seharusnya" atau das sollen, dengan menyertakan beberapa peraturan tentang apa yang harus dilakukan. Aturanaturan tersebut yang kemudian menjadi pedoman bagi individu bertingkah laku dalam bermasyarakat, baik dalam hubungan dengan sesama individu maupun dalam hubungannya dengan kelompok. Aturan-aturan itu sekaligus

30 Agus Riswanto, "Menganalisis Kesiapan Indonesia dalam Penanggulangan dan Penegakan Hukum Kejahatan Global Berbasis Internet Berdasarkan Undang-undang Informasi dan Transaksi Elektronik," Prosiding Seminar Nasional INDOCOMPAC Universitas Bakrie, Jakarta, 2016, hlm. 589.

${ }^{31}$ Ibid. 
menjadi batasan bagi masyarakat dalam membebani atau melakukan tindakan terhadap individu sehingga dapat melahirkan kepastian hukum. ${ }^{32}$

Selain kepastian hukum, diperlukan pula kejelasan hukum yang secara garis besar menjadi kepentingan hukum yang harus direalisasikan untuk mengakomodir persoalan yang timbul akibat praktik kemajuan teknologi informasi khususnya di bidang transaksi elektronik. Adapun kepentingan hukum terhadap sistem elektronik tersebut mencakup:

a. Kepentingan Hukum untuk memperoleh Kekuatan Pembuktian terhadap informasi elektronik (validity of electronic evidence).

b. Kepentingan Hukum untuk memperoleh Penyelenggaraan sistem elektronik yang baik (akuntabilitas) dengan cara penerapan prinsip upaya yang terbaik (best practices) dalam penerapan teknologi.

Kepentingan Hukum untuk memperoleh Perlindungan Hukum terhadap penyelenggaraan Sistem Elektronik tersebut sehingga mewajibkan setiap pengguna yang memperoleh manfaat untuk tidak melakukan tindakan yang bertentangan dengan hukum. ${ }^{33}$

b. Perkembangan Teknologi dan Kemampuan Hukum Menjangkau Perubahannya di Masa Depan

Melihat karakteristik teknologi informasi yang terus-menerus mengalami perkembangan dan kemajuan, maka dapat diprediksikan bahwa kedepan pun akan terjadi hal yang serupa. Jika saat ini telah terjadi kemajuan signifikan dalam teknologi khususnya terkait dengan transaksi elektronik dibandingkan beberapa tahun sebelumnya, maka dapat diproyeksikan bahwa akan terjadi hal serupa yaitu perkembangan yang lebih maju di masa beberapa tahun mendatang.

Hal inilah yang menuntut hukum untuk dapat menjangkau gambaran kondisi di masa depan. Jika hukum hanya berorientasi pada apa yang telah dan sedang terjadi saat ini, maka hukum akan terus berada di posisi satu langkah tertinggal dibanding perkembangan teknologi. Meskipun katertinggalan tersebut sebetulnya merupakan hal yang tidak dapat dihindarkan, karena permasalahan-permasalahan hukum yang terus berkembang dan sulit untuk diprediksikan.

Mengutip cara pandang Assafa Endeshaw dalam melihat persoalan ini, ia berpendapat bahwa positioning hukum di belakang perkembangan teknologi informasi tidak lantas membenarkan tidak adanya upaya pemikiran jangka panjang dalam penyusunan pengaturan hukum. Ia menegaskan bahwa

32 Peter Mahmud Marzuki, Pengantar Ilmu Hukum, Kencana, Jakarta, 2008, hlm.158.

${ }^{33}$ Ibid. 
sekalipun teknologi berkembang dengan begitu cepat dan sulit diprediksi, namun upaya pengembangan dan penyesuaian prinsip-prinsip hukum yang sudah ada merupakan langkah yang dapat ditempuh untuk merespon revolusi yang terjadi di bidang teknologi informasi. ${ }^{34}$

c. Regulasi yang ada belum efektif untuk memenuhi kebutuhan penyelesaian hukum di bidang transaksi elektronik

Berbicara tentang efektifitas hukum memang tak jarang menjebak pada sudut pandang yang subjektif. Hal ini dikarenakan ada banyak parameter yang harus dipenuhi untuk mengukur apakah sebuah hukum yang terimplementasi ke dalam peraturan perundang-undangan telah berjalan dengan baik dan memberikan dampak yang baik sehingga dapat dikatakan sebagai suatu hal yang efektif atau sebaliknya. Mengutip pendapat Soerjono Soekanto, ia menentukan parameter efektifitas sebuah hukum melalui 5 faktor, yaitu: ${ }^{35}$
a. Faktor hukum
b. Faktor penegakan hukum
c. Faktor sarana atau fasilitas pendukung
d. Faktor masyarakat
e. Faktor kebudayaan

Berdasarkan parameter tersebut, dapat dikatakan bahwa pengaturan hukum transaksi elektronik belum sepenuhnya terimplementasi secara efektif. Baik dari aspek hukum, penegakan hukum dan sarana atau fasilitas pendukung, masyarakat dan kebudayaan, semuanya belum mengindikasikan performa regulasi transaksi elektronik yang berlaku efektif di masyarakat sehingga diperlukan rekonstruksi pengaturan yang lebih efektif dan mampu menjangkau probabilitas persoalan di masa depan.

Dalam bagian ini penulis berusaha menyajikan alternatif konsep konstruksi hukum transaksi elektronik agar lebih harmonis, efektif, dan komprehensif, serta dapat mengakomodasi persoalan-persoalan seputar transaksi elektroink sesuai dengan perkembangan terkini. Rekonstruksi pengaturan hukum transaksi elektronik tersebut penulis formulasikan dalam poin-poin penjelasan berikut.

a. Undang-undang khusus tentang Transaksi Elektronik

Pengaturan Undang-undang transaksi elektronik masih terkesan abu-abu di Indonesia. Baik dari sisi penyusunan regulasinya maupun pada sisi penegakan hukum, keduanya memperlihatkan eksistensi regulasi transksi elektronik yang belum berjalan secara efektif dan maksimal. Fenomena ini menurut penulis,

${ }^{34}$ Assafa Endeshaw, Hukum E-Commerce dan Internet dengan Fokus di Asia Pasifik, terj. Oleh Siwi Purwandari dan Mursyid Wahyu Hananto, Cetakan kedua, Pustaka Pelajar, Yogyakarta, 2021, hlm. 33.

35 Soerjono Soekanto, Faktor-Faktor yang Mempengarubi Penegakan Hukum, Penerbit PT. Raja Grafindo Persada, Jakarta, 2007, hlm. 5. 
salah satunya disebabkan karena penggabungan undang-undang yang memuat transaksi eektronik dengan undang-undang yang memuat materi teknologi informasi secara umum.

Tentu penyatuan tersebut bukanlah menjadi satu-satunya masalah dalam mengambangnya implementasi peraturan transaksi elektronik di Indonesia, namun afiliasi keduanya dalam satu bentuk produk hukum nyatanya membuat porsi hukum transaksi elektronik kurang terlihat. Apalagi ditambah dengan pengaturan aspek pidana (perbuatan yang dilarang) di dalamnya, semakin menjadikan transaksi elektronik sebagai isu yang tertinggal untuk dibahas secara mendalam. Karenanya, peraturan perundang-undangan tentang transaksi elektronik yang dianaungi oleh undang-undang khusus yang memuat materi transaksi elektronik dapat menjadi solusi untuk meningkatkan pengaturan hukum transaksi elektronik di Indonesia dan menjadi bagian dari rekonstruksi pengaturan hukum transaksi elektronik yang lebih baik.

b. Model pengaturan Omnibus Law

Kompleksitas pengaturan tentang transaksi elektronik merupakan permasalahan mendasar dari sulitnya pengaturan hukum transaksi elektronik. Aspek yang begitu luas dan bersinggungan dengan berbagai lini kehidupan menjadikan teknologi informasi khususnya transaksi elektronik sebagai sisi yang tidak mudah untuk dirumuskan regulasinya karena dapat menimbulkan pesoalan harmonisasi dengan peraturan perundang-undangan lainnya. Belum lagi perkembangan teknologi yang terus melaju dengan cepat dan berimbas pada inovasi-inovasi bentuk kegiatan yang berkaitan dengan transaksi elektronik semakin menambah kerumitan pengaturannya, karena dapat menimbulkan potensi konflik hukum, kekaburan hukum bahkan ketidakpastian hukum.

Berangkat dari persoalan tersebut, opsi model hukum omnibus law menurut penulis dapat menjadi salah satu solusi yang relevan saat ini. Omnibus law dapat digunakan sebagai perangkat yang bisa membantu mengurai persoalan pengaturan hukum tranasksi elektronik yang begitu kompleks dan saling bersinggungan dengan bidang lain. Hal ini dikarenakan ominbus law dapat mengatasi konflik peraturan perundang-undangan secara cepat, efektif dan efisien, serta menyeragamkan kebijakan perundang-undangan yang telah dibuat sehingga meminimalisir terjadinya konflik hukum. ${ }^{36}$ Sehingga model ini dapat menjadi solusi peliknya pengaturan regulasi di bidang teknologi informasi khususnya mengenai transaksi elektronik.

\footnotetext{
${ }^{36}$ Friman Fready Busroh, "Konseptualisasi Omnibus Law dalam Menyelesaikan Permasalahan Regulasi Pertanahan," Jurnal Arena Hukum, Volume 10, Nomor 2 Agustus 2017, hlm. 247.
} 
Omnibus law memiliki beberapa kelebihan yaitu:

a. Mengatasi konflik peraturan perundangundangan secara cepat, efektif dan efisien

b. Menyeragamkan kebijakan pemerintah baik di tingkat pusat maupun didaerah untuk menunjang iklim investasi

c. Pengurusan perizinan lebih terpadu, efisien dan efektif

d. Mampu memutus rantai birokrasi yang berlama-lama

e. Meningkatnya hubungan koordinasi antar instansi terkait karena telah diatur dalam kebijakan omnibus regulation yang terpadu

f. Adanya jaminan kepastian hukum dan perlindungan hukum bagi pengambil kebijakan. ${ }^{37}$

Jika melihat kelebihan-kelebihan yang dimiliki model omnibus law sebagaimana diuraikan di atas, maka problematika pengaturan hukum transaksi elektronik di Indonesia seperti durasi penyusunan peraturan yang lama, bentuk pengaturan yang terbit secara terpisah dan dalam periode berbeda, persoalan efektifitas, persoalan politik hukum yang kabur, serta persoalan harmonisasi dengan peraturan perundang-undangan lainnya dapat terjawab.

\section{Penutup}

Berdasarkan uraian yang disampaikan di atas, maka dapat diperoleh kesimpulan sebagai berikut:

Pertama, terdapat banyak peraturan peraturan perundang-undangan yang mengatur tentang teknologi informasi khususnya tentang penyelenggaraan transaksi elektronik di Indonesia. Hal tersebut meimbulkan beberapa problematika, yaitu pertama, membutuh waktu yang lama untuk menyusun peraturan perundang-undangan di bawahnya. Kedua, problematika pengaturan secara parsial dalam waktu yang berbeda. Ketiga, politik hukum yang tidak jelas atau kabur. Keempat, persoalan efektifitas penerapan peraturan, dan problematika kelima yaitu persoalan harmonisasi dengan peraturan perundang-undangan lainnya.

Kedua, urgensi rekonstruksi pengaturan hukum transaksi elektronik dialatarbelakangi oleh kondisi perlunya kepastian hukum yang menjamin penyelenggaraan transaksi elektronik dapat berjalan dengan baik agar dapat tercapai kepentingan hukum. Urgensi yang kedua dikarenakan diperlukan hukum yang mampu menjangkau perkembangan dan perubahan di masa depan sehingga hukum tidak hanya berlaku secara singkat. Sedangkan urgensi ketiga yaitu dikarenakan regulasi yang ada belum efektif untuk memenuhi kebutuhan 
penyelesaian hukum di bidang transaksi elektronik sehingga dibutuhkan rekonstruksi hukum yang dapat berlaku efektif di masyarakat.

Ketiga, rekonstruksi pengaturan hukum transaksi elektronik diperlukan untuk memperoleh model hukum yang sesuai dengan kebutuhan terkini dalam hal pengaturan transaksi elektronik. Rekonstruksi tersebut dapat dilakukan dengan menggunakan dua metode, yaitu pertama, dengan membuat undangundang khusus tentang transaksi elektronik yang terpisah dengan teknologi informasi secara umum dan ketentuan-ketentuan perbuatan-perbuatan yang dilarang (cybercrime). Kedua, dengan menggunakan model hukum omnibus law hukum transaksi elektronik.

Mengacu pada pembahasan penelitian ini, maka penulis mengusulkan dua rekomendasi kaitannya dengan pengaturan hukum transaksi elektronik di Indonesia, yaitu:

1. Dilakukan revisi terhadap Undang-undang Nomor 11 Tahun 2008 tentang Informasi dan Transaksi Elektronik menjadi undang-undang baru yang memuat materi atau substansi secara terpisah antara hukum transaksi elektronik dengan hukum penggunaan teknologi informasi secara umum.

2. Perlu melakukan penyesuaian terhadap Undang-Undang Nomor 12 Tahun 2011 tentang Pembentukan Perundang-undangan untuk memasukkan konsep omnibus law beserta aturan-aturannya, mengingat secara praktik model omnibus law sudah pernah diterapkan di Indonesia dan tidak menutup kemungkinan kedepannya akan diterapkan juga untuk mengatur persoalan yang lain.

\section{Daftar Pustaka}

\section{Buku}

Asshiddiqie, Jimly dan M. Ali Safa'at, Theory Hans Kelsen Tentang Hukum, Cetakan ke-1, Sekretariat Jendreral \& Kepaniteraan Makamah Konstitusi RI, Jakarta, 2006.

Dewi, Shinta, Cyberlaw 1 Perlindungan Privasi Atas Informasi Pribadi Dalam Ecommerce Menurut Hukum International, Widya Padjajaran, Bandung, 2009.

Endeshaw, Assafa, Hukum E-Commerce dan Internet dengan Fokus di Asia Pasifik, terj. Oleh Siwi Purwandari dan Mursyid Wahyu Hananto, Cetakan kedua, Pustaka Pelajar, Yogyakarta, 2021.

Garner, Bryan A., (ed.), Black's Law Dictionary, eightgh edition, Thomson West, 2004.

Indrati S., Maria Farida, Ilmu Perundang-undangan 2: Jenis, Fungsi, dan Materi Muatan, Penerbit PT. Kanisius, Yogyakarta, 2007.

Marzuki, Peter Mahmud, Pengantar Ilmu Hukum, Kencana, Jakarta, 2008. 
Rogers, Communication Technology: The New Media in Society, 1991, terjemah oleh Zulkarnaina Mohd Mess, Teknologi Komunikasi: Media baru Dalam Masyarakat, Dewan Bahasa dan Pustaka, Kuala Lumpur, 1991.

Sikumbang, Sony Maulana, dkk., Ilmu Perundangan-undangan, Universitas Terbuka, Jakarta, 2016.

Soehino, Hukum Tata Negara: Teknik Perundang-undangan, Penerbit Liberty, Yogyakarta, 1981.

Soekanto, Soerjono. Faktor-Faktor yang Mempengaruhi Penegakan Hukum, Penerbit PT. Raja Grafindo Persada, Jakarta, 2007.

\section{Jurnal dan Prosiding}

Busroh, Friman Fready. "Konseptualisasi Omnibus Law dalam Menyelesaikan Permasalahan Regulasi Pertanahan," Jurnal Arena Hukum, Volume 10, Nomor 2 Agustus 2017.

Khan, Burhan Ul Islam, dkk., "A Compendious Study of Online Payment Systems: Past Developments, Present Impact, and Future Considerations", (IJACSA) International Journal of Advanced Computer Science and Applications, Vol. 8, No. 5, 2017.

Priowirjanto, Enni Soerja, "Pengaturan Transaksi Elektronik dan Pelaksanaannya di Indonesia Dikaitkan dengan Perlindungan E-Konsumen", Padjadjaran Jurnal Ilmu Hukum, Volume 1, Nomor 2, Tahun 2014.

Riswanto, Agus. "Menganalisis Kesiapan Indonesia dalam Penanggulangan dan Penegakan Hukum Kejahatan Global Berbasis Internet Berdasarkan Undang-undang Informasi dan Transaksi Elektronik," Prosiding Seminar Nasional INDOCOMPAC Universitas Bakrie, Jakarta, 2016

\section{Internet dan E-paper}

European Central Bank, "Glossary of Terms Related to Payment, Clearing and Settlement Systems", tahun 2009

Glossary of Banking Terms and Phrases, https://www.helpwithmybank.gov/ glossary/index-glossary.html, dikases pada 5 Juni 2021.

GSMA Association, Connected Society: The State of Mobile Internet Connectivity 2019

Kaushik Das, dkk, "The Digital Archipelago: How Online Commerce is Driving Indonesia's Economic Development", McKinseyECompany, 2018, hlm. 13. Laporan e-paper diunduh dari http://www.mckinsey.com/featuredinsights / asia-pacific/the-digital-archipelago-how-online-commerce-isdriving-Indonesias-economic-development.

The Electronic Fund Transfer Act (EFTA) (15 USC 1693 et seq.) 1978

“Transaksi Uang Elektronik Melonjak 209,8\% pada 2018", dalam https: / / databoks.katadata.co.id/datapublish/2019/09/23/transaksiuang-elektronik-melonjak-2098-pada-2018\#. Akses 11 Juli 2020. 